\title{
Development of the rational bottomhole assemblies of the directed well drilling
}

\author{
Andrii Ihnatov ${ }^{1 *}$, Yevhenii Koroviaka ${ }^{1}$, Valerii Rastsvietaiev ${ }^{1}$, and Larysa Tokar $^{2}$ \\ ${ }^{1}$ Dnipro University of Technology, Department of Oil and Gas Engineering and Drilling, \\ 19 Yavornytskoho Ave., 49005, Dnipro, Ukraine \\ ${ }^{2}$ Dnipro University of Technology, Department of Foreign Languages, 19 Yavornytskoho Ave., \\ 49005, Dnipro, Ukraine
}

\begin{abstract}
The problem of development of gas hydrate deposits is complicated by a range of problems connected with the adaptation of traditional methods and procedures to develop the mentioned type of raw materials. Construction methods of the directed well deserve high attention since they are the most efficient solution to provide a stable process of gas fraction production. Experts of the Dnipro University of Technology are at the top among the studies engaged in implementation and operation of gas hydrate deposits. Among other things, the experts have designed rational bottomhole assemblies of the directed drilling for the conditions of gas hydrate deposits. Such devices have a number of functional features. The paper describes following particularities being the most significant ones: a material to produce destructive balls and their physical properties; operating modes of a drilling process; directionality of bottomhole circulation processes as for the operational parameters of flushing fluids; and spatial location of well direction. Both calculations and bench tests favoured the process intended to identify functional features of the devices and proved convincingly the truthfulness of the initial theoretical foundations to drill the directed wells with the help of the modernized hydromechanical boring tool combined with a feeding device. The paper purpose is to analyze and substantiate structural solutions within the certain units of techniques for complex use as well as determine the rational operating schedules of the latter in the context of specific geological conditions where the directed wells are under construction.
\end{abstract}

\section{Introduction}

Like in many key countries with the developed mining industry, Ukrainian oil-and-gas economic sector is characterized by constant deepening of productive levels; complication of geological deposit conditions; extraction of minerals, which processing involves a wide range of innovative technological methods and techniques; and use of non-traditional sources of crude hydrocarbons to be mined [1-6]. Among the latter, gas hydrates are of specific interest. They are molecular compounds of water, methane, ethane, propane, butane etc. Moreover, their existence is connected with the specific values of low

\footnotetext{
"Corresponding author: ignatov.a.a@nmu.one
} 
temperatures and high pressures. In terms of calorific value, gas hydrates are comparable with bituminous oil and oil sands. Even very rough world assessments of gas hydrate reserves show that they exceed significantly the total prospected reserves of natural gas. However, following feature should be mentioned: only small share of gas hydrates can be recovered using the current industrial methods inclusive of drilling ones. Nevertheless, development of the fuel deposits needs the integrated innovative approach to design and mastering of the efficient techniques and methods [7-9].

All the activities, connected with exploration of gas hydrate deposits, their prospecting, and operation are always followed by construction of wells [10-14]. The key tasks of well drilling are as follows: studying a structure of geological section of the deposits at depth being beyond the reach of the use of other methods; specification the data of indirect techniques to analyze geological structures; and immediate development of oil-bearing levels as well as their testing $[6,12]$.

A process of a well construction is characterized as a super complex of interdependent technological operations performed to obtain a reliable link between the surface facilities and underground objects of study and development [15-17]. Composition of each operation as well as the well construction cycle on the whole is determined by means of the following factors: geographic location of the deposit; the well purpose; complexity of the geological section; physiochemical characteristics of the carbons; and thermobaric conditions of the deposits (the condition is of extra importance for gas hydrates). Any improper operation may result in certain troubles within the well shaft plus unproductive time loss and expenditures connected with its liquidation. In some cases, it may factor into loss of the well or even the deposit on the whole [18-22].

Certain geological conditions, complicating a process of well construction, are completely reasonable ones. Features of stratigraphic structure of a deposit; manifestation of various characteristics of rocks, developed by a well; abnormal pressure values within the walls and shaft of the well; and availability of definite geological structures with their specific properties are among them [23-29]. A well deepening is always followed by constant demonstration of different factors decelerating a process of well face sinking while involving the use of complex capital-intensive techniques [30-32]. Moreover, the process is complicated by the necessity to meet strict requirements as for the maintaining or artificial varying of spatial location of the well shaft depending upon the implementation needs concerning perfect system of prospecting system and the deposit development in future [33].

Thus, the minimum analysis of the current situation in oil-and-gas industry has shown that the search for tendencies to improve the efficiency and reduce capital intensity of drilling operations is the topical problem which solving will help oil-and-gas industry to move to a path of the stable innovative progress.

\section{Analysis of the recent research and publication and singling out of previously unsolved parts of the general problem}

On the whole, prospecting and mining branches are still facing the critical issue: how to improve the efficiency and achieve perfection of drilling operations [30]. The issue is rather complex, involving different components connected with the accelerated well construction in terms of simultaneous improvement of its quality and reduction or complete elimination of extra expenditures, resulting in nonfulfilment of the tasks of geological project of well construction. Especially, that concerns maintenance of the design location of a borehole path.

Practices of the world tendencies as for the industries, supplying carbonous raw materials, demonstrate the current rapid rearmament of the component of industrial complex in the majority of countries [24, 29-32]. Among other things, the phenomenon 
includes marking indicators of depletion of productive strata; worsening of reservoir characteristics of production facility; and grade characteristics of carbons as such.

Relatively easily extracted reserves of deposits, occurring at up to $3 \mathrm{~km}$ depth, have already been prospected; their natural operational capabilities are almost depleted. Nevertheless, in many cases the fact cannot be considered as the complete depletion of the levels. The matter is that in terms of the roughest evaluations, absolute hydrocarbon extraction from reservoirs is not more than 30 and even 40 units in certain cases. That is why numerous methods of secondary improvement of oil-and-gas recovery have been developed and implemented industrially. However, even the approaches are not perfect to favour significant increase in production capacity $[34,35]$. Hence, such a situation stimulated the development of the directed drilling methods being quite efficient means to engineer rational techniques for deposit mining. Moreover, they will restore productivity of the seams being at final operation stages or even those being removed from the service.

In addition to the abovementioned, the directed well drilling makes it possible to increase efficient filtration area within a well bottom zone; and improve indices of extraction from low-permeability reservoirs as well as from such ones having the developed system of vertical fissures [34]. The directed drilling methods are essential for the efficient method to develop and mine the gas hydrate deposits. It is known that gas hydrates occur within the areas of water bodies; and they have relatively complicated spatial orientation of productive strata. More than this, there is a necessity to satisfy certain geometric requirements of network of wells. In additions, there is a problem of the largest filtration area within the operational intervals of the wells. According to the estimations by prominent Ukrainian researchers, gas hydrates may exist consistently in the Black Sea at a $700 \mathrm{~m}$ depth. Foreign experts adhere to the opinion as for the depth of $725 \mathrm{~m}$ and deeper. Basing upon the reinterpretation of the retrospective research, quite real possibility is being considered concerning the availability of methane hydrates significantly shallower in the sea (even at down to $100 \mathrm{~m}$ depths) [36-39].

The abovementioned helps conclude that there is a high degree of availability of the substantial hydrate reserves in Ukrainian economic zone. However, the presented information is insufficient and fragmentary while the majority of assessments of the resources need convincing confirmation by means of prospecting drilling methods.

Gas hydrate deposits are identified using widely tested methods of seismic (acoustic) probing, gravimetry and magnetometry, measurements of thermal and diffusion flows over the analyzed areas, and studies of electromagnetic field dynamics. In this context, all the methods need branching network of wells with quite certain spatial orientation and possibility of the fullest rock sampling in the form of cores with their following complex geomorphological analysis [40-42].

In addition to the abovementioned, drilling often faces a problem of practical impossibility to perform geological tasks in terms of implementation of traditional methods which depends upon the availability of factors of random well curving and the necessity to do it artificially [33].

Hence, it goes without saying that development of the directed drilling methods and their implementation is the topical problem.

Depth deepening and associated changes in mechanical, physical, textural, and structural characteristics of rocks always stipulate deviations of a well shaft axis from the specified design direction. Rather often, the process is followed by the formation of shoulders and sharp bends within the well shaft affecting adversely all the subsequent activities.

On the other hand, if technical and technological measures are developed and implemented successfully, such aftereffects of natural well bend may be used to return its axis to the required design position [43]. 
The measures to maintain the design direction of a well axis or its variation needs: accurate information concerning demonstration of rock anisotropy [30]; consideration of the influence of a well shaft shape on the nature of its bend; development of specific facilities, included to a drill pipe, to stabilize activities of the latter relative to the certain basic indices; analysis of operating regularities of deflecting systems; and maximum consideration of nonuniformity (inadequacy) of methane hydrate deposits in terms of the deposit fluidization. The listed problems cannot be considered as all features of the directed well construction. Moreover, even the analysis of a range of problems demonstrates the issue complexity.

In view of the abovementioned, experts of the Department of Oil-and-Gas Engineering and Drilling (DOGID) of the National Technical University "Dnipro Polytechnic" focused on the search for ways to improve the directed drilling method. The ways are based upon the certain simplification of operating schedule intended to well construction [44].

Wide generalization of data by scientific sources and practices by industrial enterprises resulted in the development of innovative system of technical means consisting of a device to break up rocks on a borehole bottom differing in high degree of mobility relative to spatial orientation and the borehole bottom to develop axial load required to provide stable operation of the abovementioned drilling device.

\section{Statement of the main material}

Possibility to construct true-vertical wells 4 from a mouth 10 (Fig. 1, in terms of direction 9) or low-angle ones (Fig. 1, in terms of planes 5 and 6) are among the most important factors to improve drilling efficiency. Strict adherence to the design spatial position of the well axis is typical for them [33].

Collectively, the effect of geological conditions on the spatial location of a well under construction may be interpreted as follows: in terms of physical and mechanical characteristics, within certain bottomhole areas rock destruction proceeds at different velocities due to significant oscillations. The circumstance is always followed by a random change in the bottomhole area (Fig. 1, planes 7 and 8 ) relative to the current direction of its axis 5 and 6 . Under the conditions, change in the well axis location may take place both vertically (apsidally) 2 and horizontally 1 relative to the definite fixed direction 3 . In the majority of cases, complex spatial formation of the well direction takes place within the both mentioned planes (i.e. 1 and 2).

The expression, providing a rough idea of the general bend $\beta$, may be used for wells with complex spatial direction location. Data for the expression have been obtained from Fig. 1 and from the known trigonometric ratios:

$$
\cos \beta=\cos \theta \cos \theta^{\prime}+\sin \theta \sin \theta^{\prime} \cos \Delta \alpha,
$$

where $\Delta \alpha=\alpha^{\prime}-\alpha$.

Intensity may also be an integral characteristic of a well bend process (azimuthal or zenithal):

$$
i_{\alpha}=\frac{\Delta \alpha}{\Delta L} \text { or } i_{\theta}=\frac{\Delta \theta}{\Delta L}
$$

where $\Delta L$ - current value of the actual well depth; $\Delta \theta=\theta^{\prime}-\theta$.

Engineering prerequisites of the well direction deviation from the design one may be reduced to following components: unsuitable selection of drilling assemblies; use of the misshapen drill pipes and kellies; use of rock breaking tools being inadequate to geological and technical conditions; and availability of gaps in the tools and facilities. 


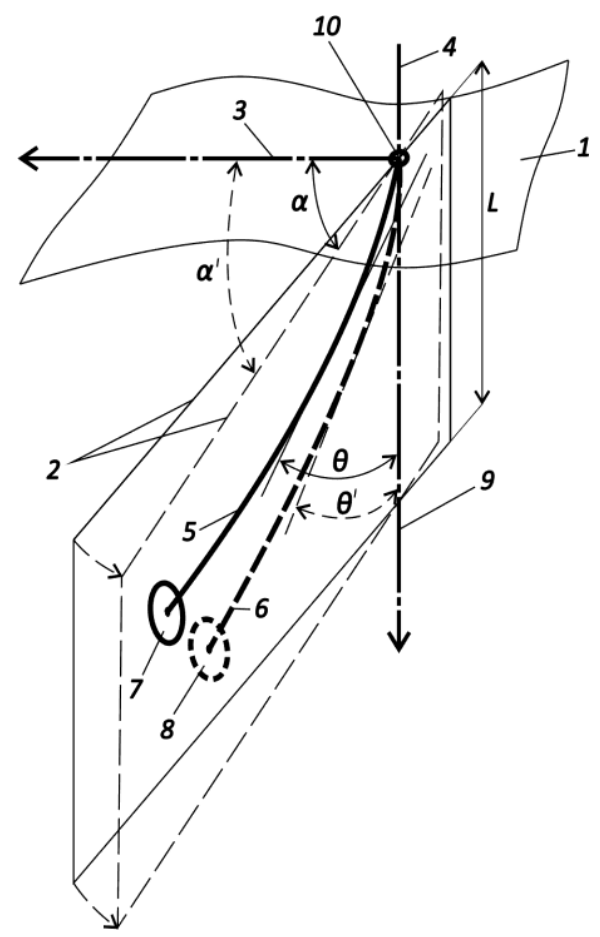

Fig. 1. Scheme of the complex spatial well location: $\alpha$ and $\alpha^{\prime}$ are design well drift angle and actual one; $\theta$ and $\theta^{\prime}$ are design zenith well angle and actual one; and $L$ is depth of a true-vertical well.

The abovementioned results in the significant eccentricity between the well axis and the tool rotation axis; its origination factors into baseless drilling out of the well shaft and inevitable deviation $\beta_{\max }$ due to deformation of the bottomhole assembly. Moreover, the drill pipe turns out to be of a screw orientation [43].

$$
\beta_{\max }=\operatorname{arctg} \frac{D-d_{v k}}{2 L_{v k}},
$$

where $D$ - a rock breaking tool diameter; $d_{v k}$ and $L_{v k}$ - diameter of a bottomhole assembly (motor) and its length respectively.

Most of all, manifestation of production factors within the processes, when spatial well location varies, depends upon the mode parameters. Among other things, it concerns axial load and rotational frequency intended for rock breaking tool. Finally, the parameters transform into the complex factors provoking complicated motion of a drill pipe within a well shaft under the action of compression, bend, twisting etc. [16].

While subtotaling, one may assume that imperfection of technical and technological support of drilling operations is among the most important reasons of changes in spatial location of a well.

In the majority of cases, the necessity to apply significant axial loads and rotational frequencies as well as operation mode of traditional rock breaking and drilling tools results in the complicated well bend. These are the reasons why today hydromechanical drilling method (Fig. 2) is most adapted to actual well conditions. If the method is applied, then bottomhole 3 shaping takes place only at the expense of effect of destructive balls 4 setting in motion with the help of some simplified jet device where a nosepiece 1 and a mixing chamber 2 are the basic working parts [45]. 


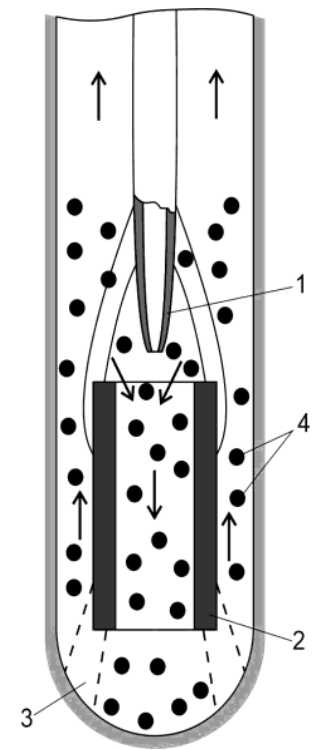

Fig. 2. Functional operational diagram of hydromechanical (impact) drilling device.

Thus, technological program of well construction has a chance to neglect formation of load and rotation. In turn, that prevents from numerous prerequisites of the well bend. Moreover, implementation process has demonstrated significant organic disadvantage of the method, i.e. formation of curvilinear peripheral bottomhole share decelerating mechanical drilling velocity and even termination of well deepening. To avoid the factor, experts of DOGID of the NTU "Dnipro Polytechnic" carried out a number of studies. Practical results are the development of innovative engineering solutions implemented in the design of hydromechanical facilities; among other things, it concerns abrasive-mechanical drilling [46].

Characteristic design of the developed hydromechanical devices makes it possible to process peripheral bottomhole area at owing to cutting and scuffing action of ball fragments on rock mass. Such a drilling procedure needs rotation of a specific rock breaking tool in the form of matrices which bottomhole zone is porous structurally. During operation, the design of a rock breaking device helps accumulate inside the ball fragments effectively.

Specific feature of the proposed device is as follows. To compare with traditional approaches, its rotation is initiated by a downhole motor being its part. The required axial load is also developed with the help of original design of adequate tool (Fig. 3) [47].

The device operates in such a way: the mechanism, included to a drilling assembly, is run on a bottomhole; upper reducing coupling 2 is used to connect a casing 1 with a drillstring; and lower reducing coupling - with a downhole motor. When the device is mounted on a bottomhole, flushing fluid is supplied. In terms of its minimum value, the whole fluid flow passes through two symmetric large 4 and small 5 circulation channels.

Then it passes through dashpots 6 consisting of a ball valve 7 and an extension spring 8 . Leaving them, it is directed to a downhole motor with the help of a channel 9 of a flanged cover 10. To activate the device, it is required to increase consumption of the flushing fluid passing through large circulation channels 4 . Since capacity of a dashpot 6 is limited by dimensions of a ball valve 7 and a spring 8 force, rather high pressure is developed in a process chamber 11 of the splined sliders 12 . Under such conditions, the splined sliders 12 overtravel a coupling 13 of a split casing 1 shifting within the inclined cavities 14 . Significance of the force, favouring shift of the splined sliders 12 and overcoming resistance of rotable springs 16 of locking elements 15 , is supported by a large surface of fluid collision. 


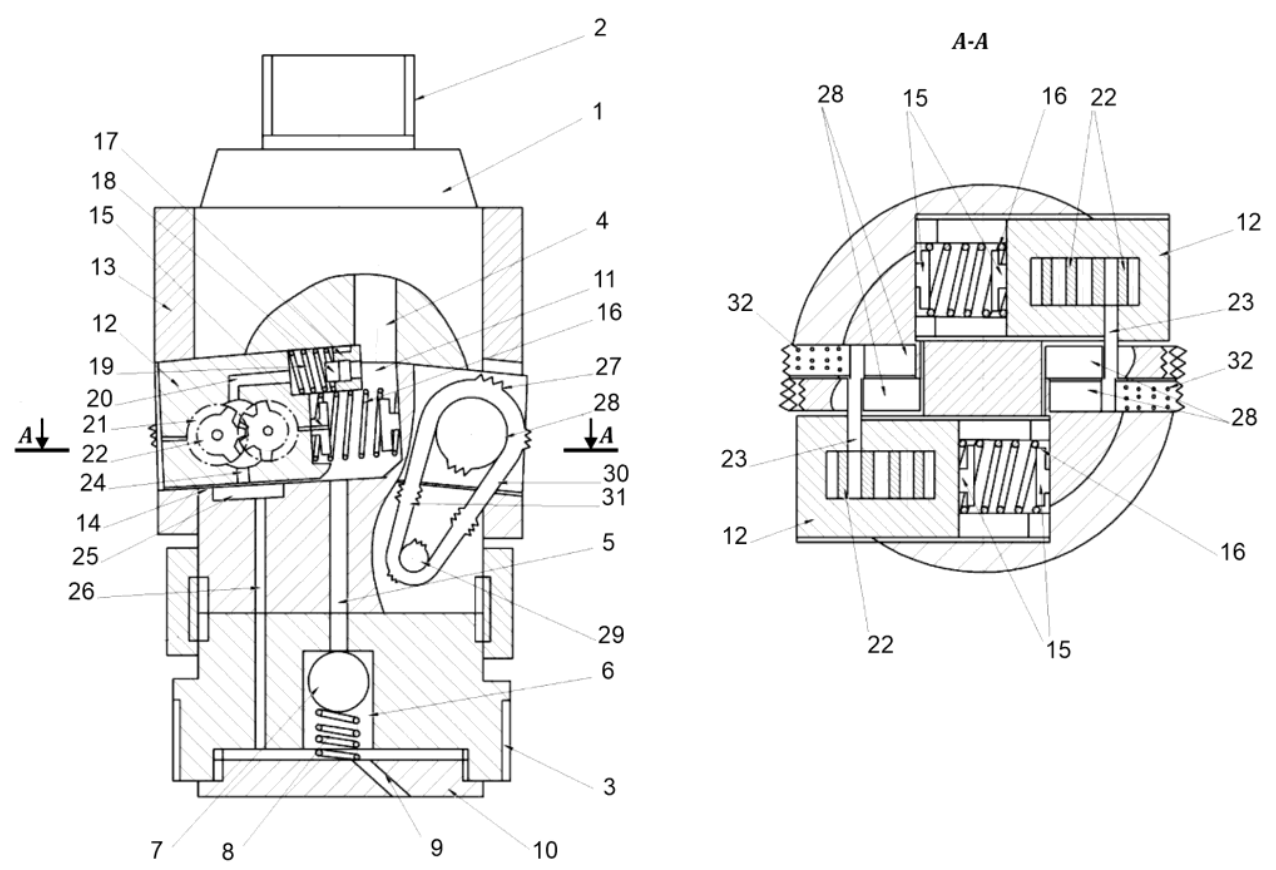

Fig. 3. Functional operational diagram of configuration of a design to develop axial load.

Moreover, response of overflow dashpot 17 takes place. The dashpot consists of a plate locking element 18 and a spring 19. Thus, using circulation channels 20 in the splined sliders 12 , the flushing fluid moves to hydraulic propulsion units 21 where two symmetric pairs of gear wheels 22 transform its hydraulic energy into rotational movement of drive shafts 23 . After the flushing fluid passes through gear wheels 22, output channel 24 helps it get into lengthwise channel 25 and auxiliary channel 26 within a split casing 1 and lower reducing coupling 3. After its leaving, the flows move to a downhole motor taking into consideration the flanged cover 10 . The shift of the splined sliders 12 towards the well walls is the necessary condition of the device operation. Moreover, the torque, originating on the drive shafts 23 , stimulates rotation of chain contact mechanisms 27 consisting of large 28 and small 29 sprockets. They are connected kinematically with the help of tool chains 32 which internal boundary is equipped by working bits 31 preventing the chain slip relative to the sprockets. External boundary is equipped by cutter bits 32 required for casing 1 defixturing within the well shaft and its shift along the well walls while the bottomhole deepening. When the cutter bits 32 get into the well walls, complete prevention from axial sideward movement of the device takes place being opposite to the face advance. The abovementioned favours a direct motion of tool chains 30 along the well walls in terms of the required axial load maintenance for the rock breaking tool to the extent being necessary for its deepening. Changes in flushing fluid supply by a drill pump control the axial intensity value as well as the split casing 1 path velocity.

Efficiency of the device to develop axial load can be estimated basing upon the comparison of well drilling indices. First of all, it concerns such a complex index as specific energy intensity characterizing labour costs per unit of the broken rock:

$$
E=\frac{2 \pi M}{h S},
$$

where $h$ - charge depth of rock breaking device; $M$ - torque; $S$ - geometry of the load area. 
Table 1 demonstrates the findings concerning the effect of pressure difference, implemented by means of the tool, on the well deepening velocity; indices of well deepening without the tool use were assumed as a comparison base.

Table 1. Findings concerning analysis of the effect of pressure difference within the device on a drilling process.

\begin{tabular}{|c|c|c|c|}
\hline No. & $\begin{array}{c}\text { Pressure difference within } \\
\text { the device, } \mathrm{MPa}\end{array}$ & $\begin{array}{c}\text { Average drilling } \\
\text { velocity } V, \mathrm{~mm} / \mathrm{s}\end{array}$ & $\begin{array}{c}\text { Increase in drilling } \\
\text { velocity, } \%\end{array}$ \\
\hline 1 & Without the device & 0.045 & - \\
\hline 2 & 3.0 & 0.052 & 15 \\
\hline 3 & 3.2 & 0.053 & 17 \\
\hline 4 & 3.4 & 0.064 & 42 \\
\hline 5 & 3.6 & 0.065 & 44 \\
\hline 6 & 3.8 & 0.069 & 49 \\
\hline
\end{tabular}

Analysis of the Table 1 data makes it possible to conclude the following: availability of the projected device as a part of the bottomhole assembly helps accelerate significantly the well deepening velocity (by $30-35 \%$ on the average). Moreover, there is a tendency to increase the velocity with the increase in the pressure difference implemented by the device. Calculations show that in terms of the proposed design of the device to develop axial load, 4.5-5.0 MPa pressure difference is a boundary achievable one. It is right the index determining a value of axial load on a rock breaking tool developed by the device.

Hence, despite the fact that the proposed tool needs such catalyzers of a well direction bend as rotation and axial load, their action is localized by direct approximation of sources of the latter to a rock breaking tool [48].

Since useful effect of the machine is just provided by means of adequate interaction between the balls and their fragments with rock mass, further bench research will be aimed at determination of rational technical and technological parameters of bottomhole contact processes.

Temporal development $T$ of destruction processes within the rock mass has been studied in terms of strength parameters being variable for destructive balls; Fig. 4 explains the results of the studies. Mechanical velocity of bottomhole deepening $u$ was an integral index of the device efficiency.

The experimental data (Fig. 4) support the idea of diverse conditions for the development of destruction processes in terms of use of balls with different mechanical characteristics. A distinct extremum of mechanical drilling velocity is available for fragile balls. The extremum corresponds to a certain degree of cutting properties, obtained by destructive elements. The abovementioned is connected with ball fracturing and, as a result, origination of sharp edges at the surface with their gradual blunting in $\mathrm{T}$ time. The last circumstance means that $u=f(T)$ graph has a descending area. Generally, operation of solid balls is characterized by stable $\mathrm{u}$ indices which may be explained by significant reserve of resistance to the action of deforming and breaking loads.

The research was carried out for coarse granite; rotation velocity was $n=260 \mathrm{~min}^{-1}$; and axial load was $C=3 \mathrm{~N} / \mathrm{mm}^{2}$ of a frontal area of the rock breaking matrices.

Considerable differences in capture and retention processes and following contact interaction between rock breaking elements and rock mass have also been identified in the context of the proposed matrices design (Fig. 5). Relying upon the data in Fig. 5, structural features of the matrices material helps it retain fragments of destructive balls which is seen clearly, if high rotation velocities are applied. At the same time, the considered processes are too complex thus requiring differential study of each factor.

The balls of $d_{k}=5 \mathrm{~mm}$ operated in rock of $9^{\text {th }}$ drillability category were used for the research; load on the matrices was $C=3 \mathrm{~N} / \mathrm{mm}^{2}$ of its edge area. 


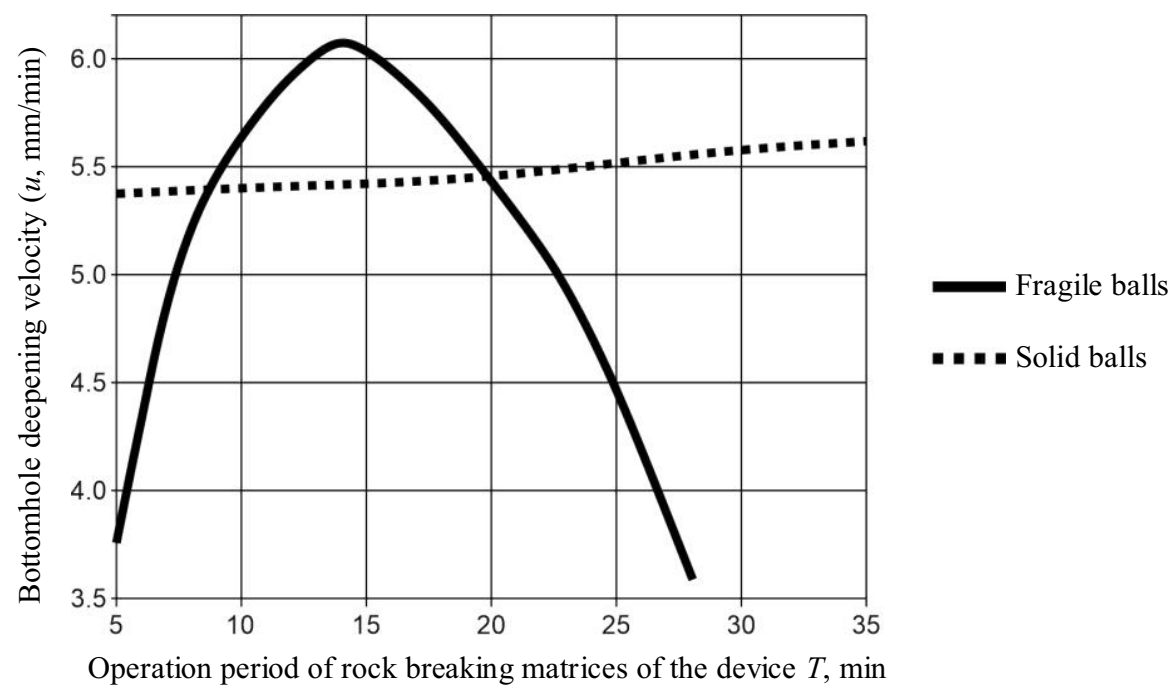

Fig. 4. Operational mechanics of rock breaking balls, manufactured from the materials differing in their strength, within the bottomhole of a simulative well.

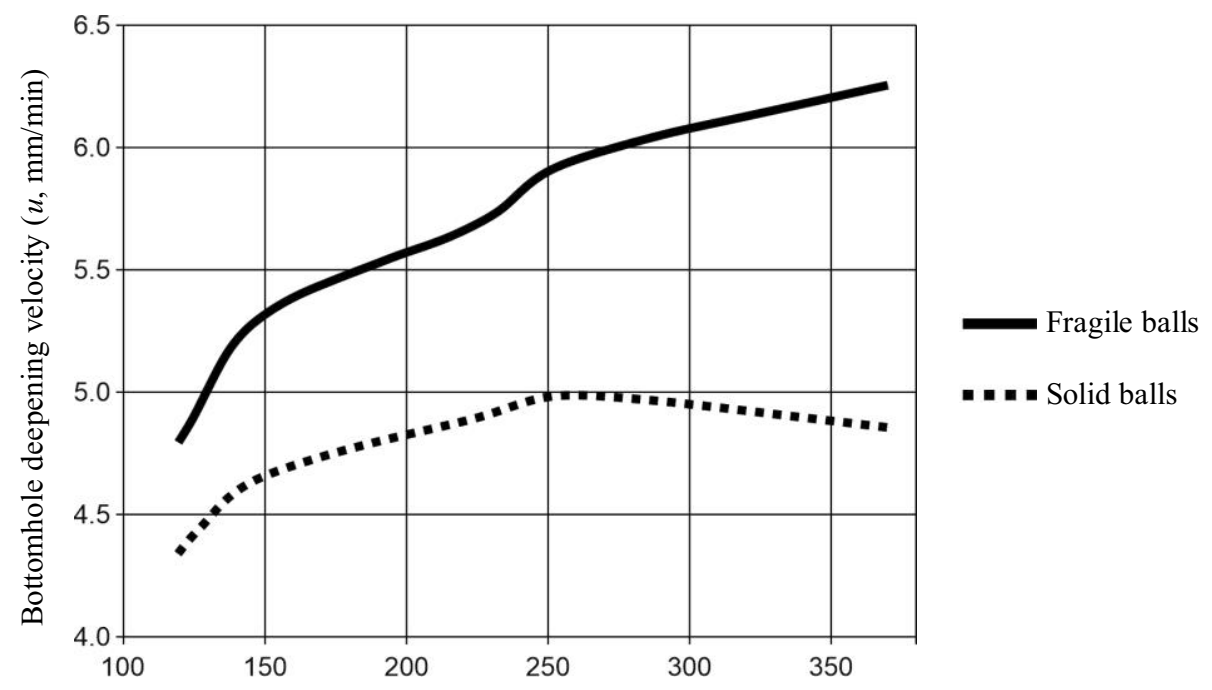

Operation period of rock breaking matrices of the device $T$, min

Fig. 5. Mechanics of contact interaction within the matrices-rock breaking elements-rock mass within the bottomhole of a simulative well.

However, the abovementioned circumstances are not sufficient to describe the differences in the operation of balls varying in their characteristics. The research has identified the regularities of abrasive interaction between the fragments and the rock braking matrices (Fig. 6). The data in Fig. 6 confirm that comparatively fragile materials are rather abrasive relative to field of matrices. The fact should be taken into consideration while developing drilling modes to prevent a potential of uneven matrices wear since that will be followed by distortion of a bottomhole assembly of a drill string with subsequent shaft bend.

The proposed technique corrects somewhat the design methods of a hydraulic system for well cleaning. 


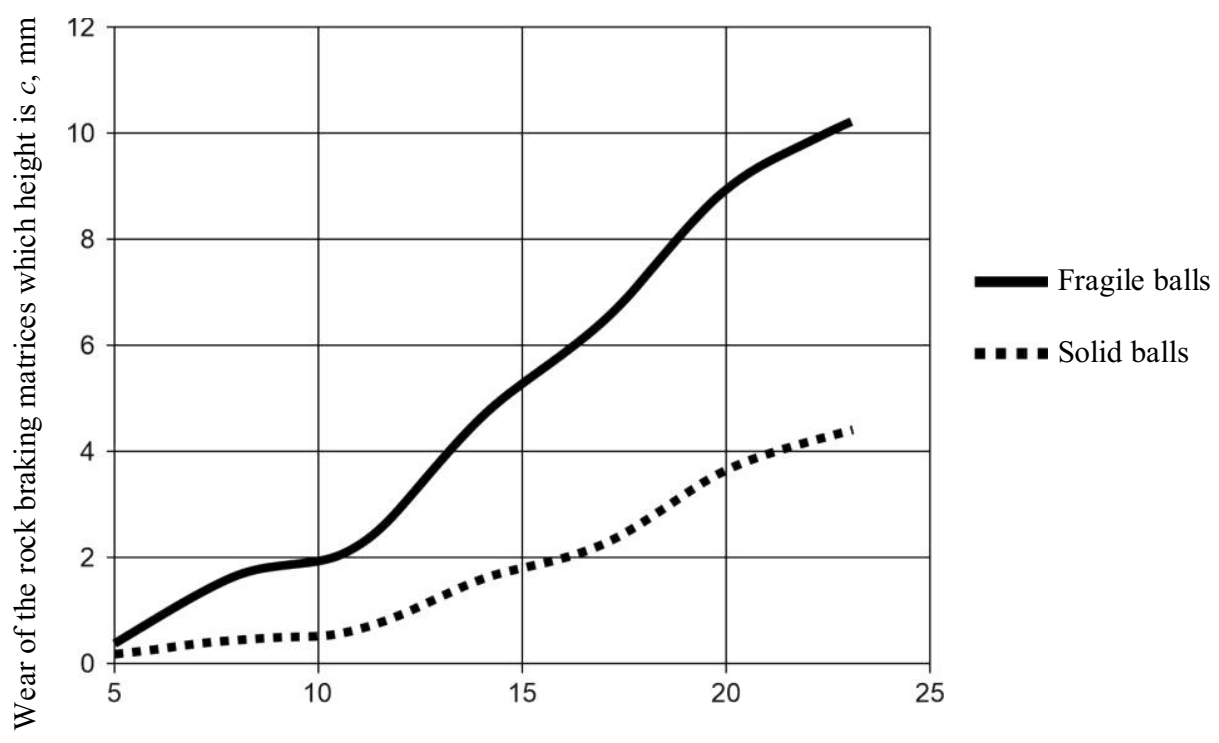

Operation period of the device matrices $T$, min

Fig. 6. Mechanics of abrasive effect of rock breaking elements on the matrices of a hydromechanical device.

In addition to its traditional function, flushing fluid should perform gravitational separation of disintegration products in terms of the modernized impact drilling to provide efficient removal of the broken rock from a bottomhole while placing and keeping the destructive elements within the field of matrices.

Table 2 demonstrates qualitative data concerning the study of compositional analysis of flushing fluids leaving hydromechanical drilling wells.

Table 2. Qualitative characteristics of a flushing fluid leaving a hydromechanical drilling well.

\begin{tabular}{|c|c|c|}
\hline No. & $\begin{array}{c}\text { Destructive bottomhole } \\
\text { conditions }\end{array}$ & Compositional analysis of a flushing fluid \\
\hline 1 & $\begin{array}{c}\text { Solid balls; low rotation } \\
\text { velocity of the device }\end{array}$ & $\begin{array}{c}\text { Rising flow contains small slurry fragments and single butterfly } \\
\text { fragments of metal which removal is uniform. }\end{array}$ \\
\hline 2 & $\begin{array}{c}\text { Solid balls; high } \\
\text { rotation velocity } \\
\text { of the device }\end{array}$ & $\begin{array}{c}\text { The number of slurry fragments somewhat increases to compare } \\
\text { with a previous variant; dimensions of fragments have increased } \\
\text { as well. Sometimes, ball fragments get to the surface. Removal } \\
\text { uniformity of disintegration products has been broken. }\end{array}$ \\
\hline 3 & $\begin{array}{c}\text { Fragile balls; low } \\
\text { rotation velocity } \\
\text { of the device }\end{array}$ & $\begin{array}{c}\text { Rising flow contains small fragments of slurry } \\
\text { and metal which removal is somewhat nonuniform. }\end{array}$ \\
\hline $\begin{array}{c}\text { Fragile balls; high } \\
\text { rotation velocity } \\
\text { of the device }\end{array}$ & $\begin{array}{c}\text { The number of slurry and metal fragments increased } \\
\text { considerably to compare with previous variant. Rather often, } \\
\text { sufficiently large ball fragments get to the surface. Uniformity } \\
\text { of disintegration product removal is not available. }\end{array}$ \\
\hline
\end{tabular}

Comparison of data, represented by Figs. 4-6 and Table 2, helps understand that operating mechanism of ball impact devices is a multifactor one requiring thorough study of the most influential factors; alongside with that, the data make it possible to support the 
idea of its great potential. The feature of bottomhole circulation processes needs the use of individual approach to design a hydraulic program for the well cleanup based upon maximum consideration of particle-size distribution of destructive products. The abovementioned will prevent from the complete insupportable wear of the tool matrices owing to the well-timed removal of abrasive particles.

The key to fulfill the condition is the use of the specific techniques helping approximate maximally the analytical data to the actual well situation. Among other things, it is proposed to apply following generalized dependence to calculate the amount of flushing fluid supplied to a bottomhole. The dependence makes it possible to identify the velocity of some particle of the broken rock [44]:

$$
u=\sqrt{l\left(\frac{\rho}{\rho_{p}}-1\right) \frac{2 g}{C}},
$$

where $l$-typical size of a particle; $\rho$-density of the particle material; $\rho_{p}$ - thickness of the flushing fluid; $g$ - gravity acceleration; $C$ - coefficient of flow resistance that depends upon a body shape and Reynolds parameter.

$$
l=\frac{V}{f},
$$

where $V$-volume of a body moving within the liquid; $f$ - area of horizontal projection of the body in terms of the most probable motion system.

Mathematical model of the particle motion within the bottomhole as well as within the well annulus is characterized completely by means of $V_{p}$ velocity connected with average velocity of a rising flow of flushing fluid $\omega_{0}$ by means of the ratio:

$$
V_{p}=\omega_{0}-u,
$$

Thorough analytical and bench studies of the methods, considered from the viewpoint of their correspondence with actual well conditions, have proved their high adequacy level.

In addition to the advantages as for the supporting stable indices of vertical wells, the proposed device provides rather acceptable conditions of the directed well drilling. Use of bent subs coupled with the directed descend of a drill string makes it possible to construct the directed wells avoiding such operations, attributal to classic techniques, as the diverter pointing.

Studies of the device operation in terms of cutting and scuffing action of ball fragments on rock mass have demonstrated following feature: as a result of manifestation of prevailing accumulation of balls and fragments on the lying well wall (being corrected if required), its bottomhole is mined within the area intensively, resulting in the shaft dropoff. The circumstance may be used efficiently while constructing horizontal wells and the wells with large zenith angles.

Thus, in terms of optimum engineering performance and technological development of the program, the designs of a device for rock breaking down a bottomhole and a face machine to develop axial load may be applied for its wide use under the corresponding mining conditions where other methods are either inapplicable or prevent from complete performing of definite geological mission.

\section{Conclusions}

Relying upon the study of scientific sources, and fundamental analysis of industrial and laboratory data, the most important factors degrading quality of drilling operations have been identified; the key tendencies of complex improvement of well techniques of the 
directed boring have been determined. Among other things, that concerns refraction as for the gas hydrate deposit development.

The basic structural performance designs have been proposed as well as specific working models of innovative facilities. In the context of multiply use, determined by means of gas feedstock recovery from hydrate deposits, they help achieve acceptable indices of well construction. Moreover, they are characterized by a significant mobility degree as for the spatial orientation.

Analytical calculations and bench tests have helped identify operational features of the designed devices for the advanced hydromechanical drilling and feeding. Their use will favour the increased drilling efficiency under the conditions when it is required either to correct the well direction or to maintain it. The abovementioned is among the most important factors to develop rational procedures of the gas hydrate deposit recovery.

The experiments and theoretical studies concerning the implementation of the directed drilling principles, relied upon the basic methods of hydromechanical effect on a bottomhole combined with the means, supporting the well direction, should be carried out in future while searching and substantiating the rational engineering solutions with maximum consideration of the specific mining and geological conditions of gas hydrate deposits being developed.

The research has been carried out by Dnipro University of Technology (Ukraine). We express gratitude to our colleagues from Department of Oil and Gas Engineering and Drilling who provide us with the required information and helped considerably complete the research.

\section{References}

1. Koroviaka, Ye., Pinka, J., Tymchenko, S., Rastsvietaiev, V., Astakhov, V., \& Dmytruk, O. (2020). Elaborating a scheme for mine methane capturing while developing coal gas seams. Mining of Mineral Deposits, 14(3), 21-27. https://doi.org/10.33271/mining14.03.021

2. Korovyaka, Ye.A., Vasilenko, Ye.A., \& Manukyan, E.S. (2014). Regeneration of methane released from landfills, and possibility of its utilization in Dnipropetrovs'k region. Heotekhnichna Mekhanika, (117), 215-224.

3. Korovyaka, Ye., Astakhov, V., \& Manukyan, E. (2014). Perspectives of mine methane extraction in conditions of Donets'k gas-coal basin. Progressive Technologies of Coal, Coalbed Methane, and Ores Mining, 311-316. https://doi.org/10.1201/b17547-54

4. Koroviaka, Ye., Rastsvietaiev, V., Dmytruk, O., \& Tykhonenko, V. (2017). Prospects to use biogas of refuse dams of Dnipropetrovsk region (Ukraine) as alternative energy carrier. Mechanics, Materials Science \& Engineering, (11), 1-9. https://doi.org/10.2412/mmse.40.34.18

5. Dudlia, M., Pinka, J., Dudlia, K., Rastsvietaiev, V., \& Sidorova, M. (2018). Influence of dispersed systems on exploratory well drilling. Solid State Phenomena, (277), 44-53. https://doi.org/10.4028/www.scientific.net/SSP.277.44

6. Dudlia, M., Sirik, V., Rastsvetaev, V., \& Morozova, T. (2014). Rotary drilling system efficiency reserve. Progressive Technologies of Coal, Coalbed Methane, and Ores Mining, 123-129. https://doi.org/10.1201/b17547-23

7. Saw, V.K., Ahmad, I., Mandal, A., Udayabhanu, G., \& Laik, S. (2012). Methane hydrate formation and dissociation in synthetic seawater. Journal of Natural Gas Chemistry, (21), 624-632. https://doi.org/10.1016/S1003-9953(11)60411-8

8. Komatsu, H., Ota, M., Smith Jr., R.L., \& Inomata, H. (2013). Review of $\mathrm{CO}_{2}-\mathrm{CH}_{4}$ clathrate hydrate replacement reaction laboratory studies - properties and kinetics. Journal of the Taiwan Institute of Chemical Engineers, (44), 517-537. https://doi.org/10.1016/j.jtice.2013.03.010

9. Su, Zh., Moridis, G.J., Zhang, K., \& Wu, N. (2012). A huff-and-puff production of gas hydrate deposits in Shenhu area of South China Sea through a vertical well. Journal of Petroleum Science and Engineering, (86-87), 54-61. https://doi.org/10.1016/j.petrol.2012.03.020 
10. Alekseev, V.I. (2013). The beetles (Insecta: Coleoptera) of Baltic amber: the checklist of described species and preliminary analysis of biodiversity. Zoology and Ecology, 23(1), 5-12. https://doi.org/10.1080/21658005.2013.769717

11. Honchar, A., \& Fedoseienkov, S. (2016). Geo- and hydroacoustic complex as a study of interconnection between processes in waters and bottom sediments. Geodynamics, 21(2), 101-108. https://doi.org/10.23939/jgd2016.02.101

12. Dreus, A., Sudakov, A.K., Lysenko, K., \& Kozhevnikov, A.A. (2016) Investigation of heating of the drilling bits and definition of the energy efficient drilling modes. Eastern-European Journal of Enterprise Technologies. Technologies, 3(7(81)), 41-46. https://doi.org/10.15587/1729$\underline{4061.2016 .71995}$

13. Dreus, A.J., Sudakov, A.K., Kozhevnikov, A.A., \& Vahalin, J.M. (2016). Study on thermal strength reduction of rock formation in the diamond core drilling process using pulse flushing mode. Naukovyi Visnyk Natsionalnoho Hirnychoho Universytetu, 3(153), 5-9.

14. Kozhevnykov, A., \& Dreus, A. (2018). Power consumption of rock decomposition process during diamond core drilling using pulse flushing. Mining of Mineral Deposits, 12(3), 22-27. https://doi.org/10.15407/mining12.03.022

15. Ihnatov, A.O. (2012). Nekotoryye voprosy razrusheniya gornykh porod pri ispolzovanii gidromekhanicheskogo snaryada. Porodorazrushayushchiy $i$ Metalloobrabatyvayushchiy Instrument - Tekhnika, Tekhnologiya Yego Izgotovleniya i Primeneniya, (15), 89-93.

16. Ihnatov, A.O. (2018). Perspectives application of coiled tubing in bore holes. Porodorazrushayushchiy i Metalloobrabatyvayushchiy Instrument - Tekhnika, Tekhnologiya Yego Izgotovleniya i Primeneniya, (21), 132-139.

17. Davydenko, O.M., \& Ihnatov, A.O. (2019). Mechanics of effective destruction of rocks by chaindrilling bits rollingcutter. Porodorazrushayushchiy i Metalloobrabatyvayushchiy Instrument Tekhnika, Tekhnologiya Yego Izgotovleniya i Primeneniya, (22), 148-157.

18. Ighnatov, A. (2016). Technological characteristics of the device for bore hole cleaning. Mining of Mineral Deposit, 10(2), 85-90. https://doi.org/10.15407/mining10.02.085

19. Ighnatov, A. (2016). Research into parameters characterizing the process of withdrawing claymud formations from bore hole vuggy zones. Mining of Mineral Deposit, 10(1), 63-68. https://doi.org/10.15407/mining10.01.063

20. Davydenko, O., Ratov B., \& Ighnatov, A. (2016). Determination of basic calculation and experimental parameters of device for bore hole cleaning. Mining of Mineral Deposit, 10(3), 52-58. https://doi.org/10.15407/mining10.03.052

21. Davidenko, A., Ratov, B., Ighnatov, A., \& Tulepbergenov, A. (2016). K voprosu o neobkhodimosti obrabotki kavernoznykh zon skvazhin. Vestnik KazNITU, 114(2), 139-147.

22. Davydenko, O., \& Ignatov, A. (2015). Some features of work of device on preparation of bore hole to fastening. Mining of Mineral Deposit, 9(4), 500-506. https://doi.org/10.15407/mining09.04.500

23. Korniyenko, V.Ya., Malanchuk, E.Z., Soroka, V.S., \& Khrystyuk, A.O. (2018). Analysis of the existent technologies of amber mining. Resources and Resource-Saving Technologies in Mineral Mining and Processing, 209-232.

24. Dychkovskyi, R., Vladyko, O., Maltsev, D., Cabana, E.C. (2018). Some aspects of the compatibility of mineral mining technologies. Rudarsko-Geološko-Naftni Zbornik, 33(4), 73-82. https://doi.org/10.17794/rgn.2018.4.7

25. Malanchuk, Ye., Korniienko, V., Moshynskyi, V., Soroka, V., Khrystyuk, A., \& Malanchuk, Z. (2019). Regularities of hydromechanical amber extraction from sandy deposits. Mining of Mineral Deposits, 13(1), 49-57 https://doi.org/10.33271/mining13.01.049

26. Malanchuk, Z., Korniienko, V., Malanchuk, Ye., Soroka, V., \& Vasylchuk, O. (2018). Modeling the formation of high metal concentration zones in man-made deposits. Mining of Mineral Deposits, 12(2), 76-84. https://doi.org/10.15407/mining12.02.076

27. Malanchuk, Z., Malanchuk, Y., Korniyenko, V., \& Ignatyuk, I. (2017). Examining features of the process of heavy metals distribution in technogenic placers at hydraulic mining. Eastern- 
European Journal of Enterprise Technologies, 1(10(85)), 45-51. https://doi.org/10.15587/17294061.2017.92638

28. Moshynskyi, V., Malanchuk, Z., Tsymbaliuk, V., Malanchuk, L., Zhomyruk, R., \& Vasylchuk, O. (2020). Research into the process of storage and recycling technogenic phosphogypsum placers. Mining of Mineral Deposits, 14(2), 95-102. https://doi.org/10.33271/mining14.02.095

29. Walter Henry Jeffery. (2015). Deep well drilling: The principles and practices of deep well drilling, and a hand book of useful information for the well driller. Palala Press.

30. Biletskyy, V.S. (2013). Concise mining encyclopaedia (in 3 volumes). Donetsk, Ukraine: Donbas.

31. Walter Henry Jeffery. (2018). Deep well drilling: The principles and practices of deep well drilling, and a hand book of useful information for the well driller. Franklin Classics Trade Press.

32. Forest John Swears Sur. (2013). Oil prospecting, drilling and extraction. Nabu Press.

33. Neskoromnykh, V.V., \& Kalinin, A.G. (2008). Napravlennoye bureniye. Moskva, Rossiya: TsentrLitNefteGaz.

34. Boyko, V.S., \& Boyko, R.V. (2005). Pidzemna hidrohazodynamika. Lviv, Ukraina: Apriori.

35. Boyko, V.S. (2004). Rozrobka ta ekspluatatsiia naftovykh rodovyshch. Kyiv, Ukraina: RealPrynt.

36. Bondarenko, V., Sai, K., Prokopenko, K., \& Zhuravlov, D. (2018). Thermodynamic and geomechanical processes research in the development of gas hydrate deposits in the conditions of the Black Sea. Mining of Mineral Deposits, 12(2), 104-115. https://doi.org/10.15407/mining12.02.104

37. Dreus, A.Yu., Bondarenko, V.I., Biletskyi, V.S., \& Lysenko, R.S. (2020). Mathematical simulation of heat and mass exchange processes during dissociation of gas hydrates in a porous medium. Naukovyi Visnyk Natsionalnoho Hirnychoho Universytetu, 5(179), https://doi.org/10.33271/nvngu/2020-5/033

38. Bondarenko, V., Kovalevs'ka, I., \& Ganushevych, K. (2014). Progressive technologies of coal, coalbed methane, and ores mining. London, United Kingdom: CRC Press, Taylor \& Francis Group. https://doi.org/10.1201/b17547

39. Pivnyak, G., Bondarenko, V., \& Kovalevska, I. (2015). New developments in mining engineering 2015. London, United Kingdom: CRC Press, Taylor \& Francis Group. https://doi.org/10.1201/b19901

40. Yuan, Q., Sun, Ch.-Y., Yang, X., Maa, P.-Ch., Maa, Zh.-W., Liu, B., Maa, Q.-L., Yang, L.-Y., \& Chen, G.-J. (2012). Recovery of methane from hydrate reservoir with gaseous carbon dioxide using a three-dimensional middle-size reactor. Energy, (40), 47-58. https://doi.org/10.1016/j.energy.2012.02.043

41. Fitzgerald, G.C., Castaldi, M.J., \& Zhou, Y. (2012). Large scale reactor details and results for the formation and decomposition of methane hydrates via thermal stimulation dissociation. Journal of Petroleum Science and Engineering, (94-95), 19-27. https://doi.org/10.1016/j.petrol.2012.06.018

42. Vagnetti, R., Boswell, R., \& Pratt, S. (2013). Researching the climate change implications of methane hydrates. Environment Coastal \& Offshore (ECO), (January/Feburary), 28-33.

43. Kalinin, A.G. (1997). Bureniye naklonnykh i gorizontalnykh skvazhin. Moskva, Rossiya: Nedra.

44. Davidenko, A.N., \& Ignatov, A.A. (2013). Abrazivno-mekhanicheskoye udarnoye bureniye skvazhin. Dnipropetrovsk, ukraina: Natsionalnyi hirnychyi universytet.

45. Davidenko, A.N., Ratov, B.T., Pashchenko, A.A., \& Ignatov, A.A. (2018). Vliyaniye gidrostaticheskogo davleniya na udarnoye abrazivno-mekhanicheskoye bureniye skvazhin. Almaty, Kazakhstan: Kaspiyskiy obshchestvennyy universitet.

46. Ihnatov, A.O., \& Viatkin, S.S. (2013). Kulestrumynnyy prystriy dlya burinnya sverdlovyn. Patent No. 102708. Kyiv, Ukraina.

47. Ihnatov, A.O. (2017). Prystriy dlya stvorennya osovoho navantazhennya. Patent No. 114966. Kyiv, Ukraina.

48. Vyrvinskyy, P.P., Kuzin, Yu.L., \& Khomenko, V.L. (2010). Heolohorozviduvalna sprava $i$ tekhnika bezpeky. Dnipropetrovsk, Ukraina: Natsionalnyi hirnychyi universytet. 